\title{
Religiosity and Technology in Community Information Group
}

\author{
Manik Sunuantari ${ }^{1}$, Mayda Putri Setyastuti ${ }^{2}$ \\ University of Al Azhar Indonesia Jakarta ${ }^{1}$, University of Diponegoro Semarang ${ }^{2}$ \\ \{maniksunuantari24@gmail.com¹, maydaps@gmail.com $\left.{ }^{2}\right\}$
}

\begin{abstract}
Community Information Group (CIG) is a public service entity that is founded and managed by some community agents who aim to informing and empowering the community through the activity of information dissemination. This study is focused on CIG Pasir Kramat Kraton Kota Pekalongan, which is acclaimed as one of the leading CIG among hundreds in Indonesia due to its various achievements. The community regard the technology not only as an instrument to share and publish information among community members, but also as an instrument to preserve their culture and tradition. The usage of the information technology is expected to go hand-in-hand with the preservation of their local wisdom, such as local dialect, and religiosity. The objective of this research is to explore local cultures as the identity of Pekalongan City which has been well-preserved and well-developed even in the era of Society 5.0. This is a qualitative research using Ethnography of Communication. The finding of this research showed that the emergence of Society 5.0 concept which is characterized by the usage of technology in daily basis do not have any significance to lessen the will of community to preserve and develop their existing local wisdom. The concept of society 5.0 has been accepted by the community as the latest product of civilization, and play a positive role in the perseverance of local culture. Communication and information technology is particularly not vanishing the local value, including religiosity, which has been existed in the daily life of Pekalongan people.
\end{abstract}

Keywords : CIG; ICT; Local Wisdom; Religiosity; Ethnography

\section{Introduction}

The emergence of the industrial revolution 4.0 has changed human life, especially in the economic field, even changing the order of the world of work. Internet technology 4.0-based industrial revolution gave rise to many new opportunities, namely creating a variety of new jobs in the industrial field that had not been thought of before. The rise of new businesses based on digital technology is inevitable, various innovations occur. People's lifestyles also change with the advent of digital technology. Increasing the capacity of human resources must continue to be encouraged to be able to adopt technology so that Indonesia is able to compete with other countries. These transitions could be surface constraints in the labor market, for reasons ranging from lower wages to cultural and gender bias, but also present new 
opportunities for work and job growth [1]. Industry 4.0 is determined as an umbrella term used to describe a group of connected technological advances that provide a foundation for increased digitization of the business environment [2]. The Fourth Industrial Revolution stimulates open connections, that is, open innovation, between technology and the market, while IT spreads across primary, secondary, and tertiary industries, and dynamic new combinations between technology, the market, and society are formed [3]. The fourth industrial revolution is more than just technology-driven change. Rather, it is powered with disruptive innovation to positively impact our core industries and sectors, such as education, health and business [4]. Utilization of ICT in all aspects of community life is not something that is easily accepted, given the diverse conditions of society. So that it takes a lot of effort from various parties to quickly adjust to existing changes.

Implementation of digital technology causes some serious changes, one of it are cultural changes. The city of Pekalongan in Central Java Province, known as the City of Batik, is often referred to as the World City of Batik and continues to make various changes related to the industrial revolution 4.0. Governments and policy makers need to adapt and react quickly to the rapid evolution of the Industry 4.0 landscape by providing the enabling environment, safeguards, and policies that can guide the future for sustainable economic and social development and that harness the promise that the technologies arising from Industry 4.0 hold for people and societies [5].When in 2014 Pekalongan was chosen as one of the World Creative Cities Network in the category of Craft and Folk Art by UNESCO, not only representing Indonesia, but also representatives from Southeast Asia, the government of Pekalongan city continued to promote the ICT revolution. Almost all facilities from health, education, to trade utilize digital technology. On the other hand, the city of Pekalongan is also famous for its religious city, the majority of the population is Muslim, even though the value of pluralism is high. The population consists of Javanese, Arabic and Chinese who live side by side with high tolerance. This of course will support the readiness of the public in adopting the industrial revolution 4.0.

Utilization of information technology is directed at public awareness of the importance of technology in information management. ICTs are general purpose technologies and permeate production and consumption activities [6]. When individuals engage in everyday interactions, they act in ways that are both enabled and constrained by social structure: the social context, history, structures of interaction, and attributes that individuals bring to the interaction [7]. The presence of the Community Information Group (CIG) in the midst of the community provides a space for discussion for the community on various issues facing the community. In accordance with technological developments, the community together with CIG also use ICT in building awareness to improve welfare. The community is able to manage information independently according to their individual needs. In Buru Regency, Empowerment Community is an effort to provide opportunities to the community at the same time the ability to play an active role in the development. One of the positive impact of the program implementation, is the community is able to take responsibility towards their work [8]. Volunteering can fill an important need by rounding out the academic education received by those studying community development [9].

This study focused on CIG Pasir Kraton Kramat, Pekalongan, as one of the leading CIG among hundreds in Indonesia due to its various achievements. The existence of CIG in Pekalongan has been encouraged by Decree of the Mayor of Pekalongan No.555 / 524, 2015, concerning The Establishment of Village Community Information Groups in Pekalongan City, including CIG management structure. CIG are meant to support various policies made by the Pekalongan City Government, it is deemed necessary to form a Community Information 
Group (CIG) as a government partner in the dissemination of public information. CIG has adopted ICT to disseminate information and other communication activities, while Pekalongan city in the other hand is a city of culture and heritage with many local values, including religion are situated in their people daily life. This research would like to explore how ICT and local values interacted in CIG dissemination information activities.

\section{Method}

This study uses qualitative methods, with the type of ethnographic communication research. Ethnography of communication focuses on various communicative behaviors (communicative competence) in speech communities, patterned communication and regulated as a system of communicative events, and ways of interacting with other cultural systems [10]. According to Hymes, at the level of individuals and groups who interact with other parties, communication functions are directly related to the goals and needs of participants [11]. The location of this research is the village of Pasir Kraton Kramat located in Pekalongan City, the subject of the research is CIG Pasir Kraton Kramat with a focus on activities carried out by CIG in managing information related to various policies made by the local and central government. Management of information by utilizing various media in community empowerment, especially new ICTs. As informants are CIG members who are also musicians of Jawan Al-Imani, Pekalongan City and several parties that are connected with CIG activities.

\section{Result and Discussion}

\subsection{Empowerment of Communication Information Technology-Based Communities}

The presence of CIG is tailored to the needs of the community, because CIG is from and for the community, so it is buttom up. The active role of the community strongly supports CIG activities. In its activities, CIG did ADINDA (Director General of Indonesian Ministry of Communication and Information, IKP, 2015, 27-33), namely: Information Access (Akses Informasi); Information Discussion (Diskusi Informasi); Implementation (Implementasi); Networking (Networking); Information dissemination (Diseminasi Informasi); Aspiration Advocacy (Advokasi Aspirasi)

"ADINDA" activities are carried out in order to realize information networks and two-way communication media between CIG and the community, the community and the government or the community and other institutions. All activities are directed in the context of empowering the community and promoting economic prosperity. In accordance with the activities carried out, in managing CIG information functions are: (1) A vehicle for communication of information, CIG is a bridge for individuals and groups to exchange information with fellow CIG members, related parties, and the community in general.; (2) A vehicle for community change, CIG is expected to play a role in empowering the community to have the ability to solve their own problems with their own resources and initiatives; (3) A vehicle for community economic empowerment by utilizing information as added value to achieve prosperity and improve living standards. Especially in optimizing the use of ICTs to support activities carried out by the community.

\subsection{Culture Village as the Identity of Pekalongan City}


The presence of CIG in each Sub District provides a breakthrough in bridging the flood of information. The increasing number of CIG in terms of quantity must be followed by strengthening the capacity of CIG human resources. Pekalongan City Government through Diskominfo continuously makes simultaneous efforts in providing guidance and direction as one of the functions of Diskominfo as a facilitator. Various forms of training related to the use of information and communication technology, including mastery of computers and the internet. This was done in order to spur CIG in accessing and disseminating information using various sources. Even in the context of accelerating the mastery of information technology, each village is placed with a telecenter. Through this telecenter it is hoped that CIG can obtain, and disseminate information in their environment. In the end, all CIG members mastered information technology albeit gradually.

On the other hand, the preservation of local cultural values is a must, based on Pekalongan Mayor Regulation No.36 of 2018, concerning Tourism Villages and/or Cultural Villages, it is stated that Cultural Villages is an area in the village area that has good tangible cultural elements as well as intangible which are still clearly displayed in daily life and the community is trying to preserve and develop them. With the formation of Kampung Budaya as a means of exchanging information, communication and cooperation between citizens, communities can express their aspirations and problems that occur in their area. The management principles of Kampung Budaya are: (a) Sustainable economic, social, and cultural development; (b) Protect the environment; and (c) Maintain uniqueness, authenticity, wisdom, local, and specific.

One of the local wisdoms of CIG Kraton Pasir Kramat is the traditional musical art of Flying Jawan. In 1970-1980 the music of Flying Jawan still survived in 45 villages in Pekalongan City. But until 2007, only one survived, namely the Jawan Al-Imani Kraton Kidul group. The musical arrangements of Jawan Al-Imani continue to be developed according to the development of the times while still trying to develop local wisdom. Various song themes such as: Jamkesmas, cleanliness, security, education, and activities to build harmony in religious diversity, as well as other development information that is felt necessary for the public to know.

\subsection{Pekalongan City Communication Information Technology (ICT) Revolution}

Pekalongan City is located on the lowland coast of the northern coast in the province of Central Java. The poverty reduction in Pekalongan City is one of the people's awareness in the empowerment process. The active role of the community in accessing various information according to needs is one of the keys to creating prosperity. This is done considering the importance of CIG at the village level in encouraging community involvement in development by utilizing various available information. Through the decree, the CIG Forum in Pekalongan City was formed, which is a collection of CIG from various villages. Focus of the activity which is Preferred by CIG is increasing access information for groups and communities hopefully it can maximally utilized to improve economic life [12].

The maximum use of ICTs in the City of Pekalongan in order to support development progress in the fields of economy, education, health, culture, and other projects outside of existing policy programs. In the socioeconomic and environmental field, Pekalongan City developed 2 scenarios, namely [13]: (1) Based on the development of sustainable development activities; (2) Based on the concept of "meaningful broadband" ecosystems, that all ICT dimensions are improved and integrated to get maximum results. Both scenarios were developed in order to encourage the participation of the community, business institutions in the development of ecosystems. To anticipate the explosion of internet-based business. then 
online trading in the city of Pekalongan increasingly widespread, as there is business.pekalongan.com. A number of ICT applications have been operated in Pekalongan City in order to reduce the use of paper with the "paperless office" model. Since 2015, Pekalongan City has used FOSS (Free Open Source Software) option, with the motto "We love legal software, but Free Open Source Software is Our Choice". It is hoped that with this motto, open source can be an alternative choice for sharing information both experiences, problems, best practices, and so forth.

In order for communication between the community and the government to run smoothly, the Pekalongan City Government made telecentres that were equipped with technology and communication applications. Telecentres include Community Access Points (CAP) and Mobile Community Access Points (M-CAP). Community Access Points (CAP) have ICT learning service functions and internet access. The Pekalongan City Government currently has 47 telecenters from the Community Empowerment Institute (LPM) in each Pekalongan City village. The next phase will be widened at the RW / RT level and 400 Posyandu in Pekalongan City. While the Mobile Access Point (M-CAP) functions as an ICT learning service, internet access, telephone service access, and information dissemination through audio visuals, only one unit is available. Telecentres also function as a center for information search in various fields including promotional and marketing activities.

\subsection{Digitalization, Religiosity, and Local Wisdom}

Since the initiation of the FOSS program as a way of migrating various forums was used to introduce the program. As a form of change, the Regional Government of Pekalongan City has experienced various difficulties, starting from the difficulty of using applications, the availability of human resources, as well as the existing network. However, efforts are continuously made to remain optimistic that migration can be carried out. To achieve the implementation of migration to legal software based on open source in Pekalongan City, there are 7 main things that cannot be separated, namely:

a. Legalizing the use of ICT infrastructure in the Pekalongan City government environment. This is done in maintaining the authority of the government in maintaining the dignity and integrity of regional governments in the community;

b. Realizing efficiency in investment and utilization of ICT infrastructure;

c. Migration is intended to create sustainable technology development in the long run;

d. FOSS encourages independence so that opportunities for various fields of development are opened, especially in community empowerment;

e. Realizing barokah management in the administration of government, so that the image of the regional government in the eyes of the community becomes good;

f. Encouraging innovation in various institutional organizations, the FOSS program becomes an engine of innovation, each party must continually learn so that it can accept new things in accordance with the traditions, beliefs, culture in society;

g. Building awareness of ICTs as enablers, accelerators, and transformers in the administration of regional government so that the government is responsive, accountable and of high quality.

In relation with the Industrial Revolution 4.0 and 5.0, the Government of Pekalongan City continues to make improvements in the use of ICTs in various sectors. This becomes a necessity that the people of Pekalongan city can utilize various ICTs in order to improve their standard of living. Various information can be accessed easily by the public so that it accelerates the process of independence. People are not only information literate, but they are 
able to utilize information so as to provide added value economically. Efforts are continuously made not only through events created by the government, but can originate from the people. The government can build partnerships between CIG and stakeholders from other institutions, even business institutions. Thus the economy in the city of Pekalongan can grow and encourage the creation of sustainable community empowerment.

The CIG Pasir Kraton Kramat information group uses ADINDA stages, an effort to encourage an independent and empowered community is carried out by utilizing ICTs and other media that are familiar to Pekalongan residents. One that is often used by CIG is Jawan music, the art of music as a cultural heritage in Pekalongan. Music Jawan as one of the Pekalongan cultural heritage was not spared in making adjustments of the times. In every song that is sung does not always contain traditional messages, or praise to the Prophet Muhammad, but also contains messages of development, especially relating to problems faced by the community at that time. Therefore it takes creativity from the Jawan Al-Imani group to compose songs containing the message of development without losing the principles of Jawan's musical art itself. CIG Pasir Kraton Kramat has proven that traditional art is capable of acting according to the demands of the times. So that in building the independence of the media community that is currently dominantly used is digital-based media, such as Facebook, YouTube, WhatsApp, Instagram, and Jawan's music media. Besides that, the media of announcement boards, brochures, face-to-face meetings, and Batik TV (local television managed by the Pekalongan city government).

Although Jawan's music game is sometimes sung in Arabic and Javanese with a combination of percussion and guitar, the language often used is Indonesian. As one of Pekalongan's distinctive music, Jawan's music often performs official Pekalongan government events, even activities involving other countries. The art of Jawan music is a local term used by the Pekalongan community, which originally contained songs of praise to Allah SWT based on the Barzanji book. However, in its journey tailored to the needs of the community, the contents of the song use more a combination of praise and information about development, information related to improving the quality of life of the community in health, education, and economy.

By maintaining Javanese traditions, people are able to improve their lives better, although not only material needs, including immaterial or spiritual needs. One of the beliefs of the community is to maintain the safety of the world both physically and mentally. The concept of 'Memayu Hayuning Bawana' [14] is considered to have a high religious value, that to realize safety, happiness, and welfare of life, each member of the community is able to get rid of low passions. According to Daradjat [15], the most important form of religiosity is someone can feel and experience it thought about God, the last days and other components of religion. Always do good and put together life together, set an example for others. These behavioral attitudes must be applied in one's relationships with other people and society. People are considered successful in life if they can maintain social order, harmony and order in the community and society. People who are able to carry out memayu hayuning bawana will be able to maintain the unity and integrity of the nation, the state, and even the world. So that the principle of welfare is not seen only materially successful. In relation to the social environment, Pekalongan residents adhere to the principle of memayu hayuning bawana, there must be a balance between physical and spiritual needs.

\section{Conclusion}


Government of Pekalongan City continues to make improvements in the use of ICTs in various sectors to improve the living standard of the people. Implementation of ICT in CIG is mainly seen in "ADINDA" stages. "ADINDA" is an effort to encourage and empower community by utilizing ICTs and other media that are familiar to Pekalongan residents. One that is often used by CIG is Jawan music, the art of music as a cultural heritage in Pekalongan. Traditional media, such as Music Jawan contains not only traditional and religious messages, but also contains messages of development, especially relating to problems faced by the community at that time. In this case, the emergence of Society 5.0 concept which is characterized by the usage of technology in daily basis do not have any significance to lessen the will of community to preserve and develop the existing local wisdom and local cultures. While empowerment of the community is expected to bring economic welfare, people of Pekalongan, especially people of Pasir Kraton Kramat, still regard the spiritual welfare as the main goal. Memayu Hayuning Bawana is the soul and the goal. This principle is translated as religiosity element in this study. People who are able to carry out this principle would be able to maintain the unity and integrity of the nation, the state, and even the world as it taught the people to maintain balance between physical and spiritual needs.

\section{References}

[1] J. Bughin, J. Manyika, and J. Woetzel, "Jobs lost, jobs gained: Workforce transitions in a time of automation," 2017.

[2] Skobelev and Borovik, "On The Way From Industry 4.0 to Industry 5.0: From Digital Manufacturing to Digital Society,” Int. Sci. J., vol. II, no. 6, pp. 307-311, 2017.

[3] M. H. Lee et al., "How to respond to the Fourth Industrial Revolution, or the second information technology revolution? Dynamic new combinations between technology, market, and society through open innovation," J. Open Innov. Technol. Mark. Complex., vol. 4, no. 3, pp. 1-24, 2018.

[4] M. Xu, J. M. David, and S. H. Kim, "The fourth industrial revolution: Opportunities and challenges," Int. J. Financ. Res., vol. 9, no. 2, pp. 90-95, 2018.

[5] R. Morrar, H. Arman, and S. Mousa, "The Fourth Industrial Revolution (Industry 4.0): A Social Innovation Perspective," Technol. Innov. Manag. Rev., vol. 7, no. 11, pp. 12 20, 2017.

[6] L. Adarn et al., From the Digital Divide to DIGITAL OPPORTUNITIES. Canada: Claude-Yves Charron, 2005.

[7] N. M. M. Dowell, T. M. Nixon, and A. C. Graesser, "Group communication analysis: A computational linguistics approach for detecting sociocognitive roles in multiparty interactions," Behav. Res. Methods, vol. 51, no. 3, pp. 1007-1041, 2019.

[8] M. C. B. Umanailo et al., "Empowerment Community in Buru Regency," in Proceedings of the International Conference on Industrial Engineering and Operations Management, 2019, pp. 2070-2075.

[9] E. PARKES, "Rethinking the true impact of voluntourism in line with new community development standards," WHANAKE Pasific J. Community Dev., vol. 4, no. 2, pp. 90101, 2018.

[10] M. Saville and Troike, The Ethnography of Communication: An Introduction, Third Edit., vol. 18, no. 4. United Kingdom: Blackwell Publishing, 2003.

[11] A. S. Ibrahim, Panduan Penelitian Etnografi Komunikasi. Surabaya: Usaha Nasional, 1994. 
[12] M. Sunuantari, A. Bajari, N. A. Damayani, and M. Hubeis, "MEMBANGUN MASYARAKAT INFORMASI BERBASIS KELOMPOK," WACANA, vol. XIV, no. 4, pp. 355-371, 2015.

[13] Technopreneur Indonesia, Revolusi TIK dari Batik Pekalongan. Pekalongan: CV Alfada, 2015.

[14] S. Endraswara, Memayu Hayuning Bawana: Laku Keselamatan dan Kebahagiaan Hidup Orang Jawa. Yogyakarta: NARASI, 2013.

[15] R. Mayasari, "Religiusitas Islam dan kebahagiaan (Sebuah telaah dengan perspektif psikologi)," Al-Munzir, vol. 7, no. 2, pp. 81-100, 2014. 